\section{Hacettepe Üniversitesi Sosyal Bilimler Meslek Yüksekokulu Öğrencilerinin İş Değerleri ve Kariyer Seçimlerinin Doğrusal Olmayan Kanonik Korelasyon Analizi İle Değerlendirilmesi}

\author{
Yrd. Doç. Dr. Nesrin AKCA \\ Kırıkkale Üniversitesi, Sağlık Bilimleri Fakültesi \\ Sağlık Yönetimi Bölümü, nakca@kku.edu.tr \\ Öğr. Gör. Dr. Selen YILMAZ IŞIKHAN \\ Hacettepe Üniversitesi, Sosyal Bilimler Meslek Yüksekokulu \\ seleny@hacettepe.edu.tr
}

\section{Hacettepe \\ Üniversitesi \\ Sosyal Bilimler \\ Meslek \\ Yüksekokulu \\ Öğrencilerinin İş \\ Değerleri ve \\ Kariyer \\ Seçimlerinin \\ Doğrusal \\ Olmayan \\ Kanonik \\ Korelasyon \\ Analizi İle \\ Değerlendirilmesi}

\begin{abstract}
Özet
Amaç: Bu çalışmanın amac1, üniversite öğrencilerinin kariyer seçimlerini hangi faktörlerin etkilediğini belirlemek ve iş değerleri ile kariyer seçimleri arasında bir ilişki olup olmadığını ortaya koymaktır. Çalışmada; öğrencilerin demografik özellikleri, iş değerleri ve kariyer seçimleri arasındaki ilişkiler incelenmiştir.

Yöntem: Veri toplama aracı olarak Super' in iş değerleri envanteri ve Holland'ın kariyer seçme envanteri kullanılmıştır. İş değerleri; fedakarlık, estetik, yaratıcılık, entelektüel teşvik, başarı, bağımsızlık, prestij, yönetim, ekonomik kazanç, güvenlik, çevre, yönetici ile ilişkiler, iş arkadaşları ile ilişkiler, yaşam tarzı ve değişikliktir. Holland'ın kariyer seçme envanteri; "gerçekçi", "araştırmac1", "sanatç1", "sosyal”, "girişimci" ve "geleneksel” olmak üzere altı faktörden oluşmaktadır. Açıklayıcı faktör analizi sonucunda, yedinci faktör "pazarlıkçı" olarak çalışmaya eklenmiştir. Herbir faktörü kapsayacak şekilde hazırlanan toplam 34 yargı, beşli likert tipi ölçekle değerlendirilmiştir.

Anketin uygulanması 2012-2013 eğitim öğretim yılında Hacettepe Üniversitesi Sosyal Bilimler Meslek Yüksekokulu'nda gerçekleştirilmiştir. Çalışmada öğrencilerin demografik özellikleri ile iş değerleri ve kariyer seçimleri arasındaki ilişkiyi ortaya koyabilmek için Doğrusal Olmayan Kanonik Korelasyon Analizi'nden (OVERALS) yararlanılmıştır.
\end{abstract}


İsletme Bilimi Dergisi (JOBS), 2017; 5(1): 49-70. DOI: 10.22139/jobs.289552

Hacettepe

Üniversitesi

Sosyal Bilimler

Meslek

Yüksekokulu

Öğrencilerinin İş

Değerleri ve

Kariyer

Seçimlerinin

Doğrusal

Olmayan

Kanonik

Korelasyon

Analizi İle

Değerlendirilmesi

50
Bulgular ve Sonuç: İlk olarak kullanılan iş değeri ve kariyer seçimi ölçekleri için güvenirlik analizleri yapılmış Cronbach Alpha değerleri sırasıyla 0.929 ve 0.882 olarak bulunmuştur. Yapılan küresellik testi sonucunda $\mathrm{p}=0.000<0.05$ bulunmuş olup değişkenler arasındaki ilişkilerin \% 95 güven düzeyinde önemli olduğu söylenebilir.

Anahtar Kelimeler: Kariyer, kariyer seçimi, iş değerleri, üniversite öğrencisi, doğrusal olmayan kanonik korelasyon analizi.

\section{The Assessment of Work Values And Career Elections of The Students of Hacettepe University Vocational School of Social Sciences By Non-Linear Canonical Correlation \\ Analysis}

\begin{abstract}
Purpose: The purpose of this study is to determine the factors influencing career choices of university students and to reveal whether there is a relationship between work values and career choices. In this study, relationships between the students' demographic characteristics, work values and career choices were examined.
\end{abstract}

Method: As a data collection tool Super's work values inventory and Holland's career choice inventories were used. Work values are altruism, aesthetics, creativity, intellectual encouragement, success, independence, prestige, management, economic gain, safety, the environment, relationships with managers, relationships with colleagues, lifestyle, and change. Inventory of Holland's career choice is made up of six factors which are realistic, researcher, artist, social, entrepreneur and traditional. As a result of the exploratory factor analysis, the seventh factor was added to study as a "bargain". A total of 34 jurisdictions prepared to cover each factor was evaluated by five-point Likerttype scale.

Implementation of the survey was conducted at Hacettepe University School of Social Sciences in 2012-2013 academic year. In this study, to elucidate the relationship between students' demographic characteristics, work values and career choices, Nonlinear Canonical Correlation Analysis technique was used.

Findings and Result: First of all, Reliability Analysis were made for the scales used in the work value and career choice and Cronbach's alpha values were 
found 0.929 and 0.882 respectively. As a result of the Sphericity Test, $p$ value was found to be less than 0.05 . Therefore, it is concluded that the relationship between variables is in the confidence level of $95 \%$.

Key Words: Career, career choice, work values, university students, non-linear canonical correlation analysis.

\section{Giriş}

Değerler, kişinin amaçlarını, yaşam tarzını, işe motivasyonunu, davranışlarını ve memnuniyetini belirlemede önemli bir unsurdur. Aynı zamanda, bireyin değerleri, mesleki eğilimlerini de göstermektedir. İş değerleri, kişinin iş yaşamı boyunca elde etmeyi arzuladığı amaçlar ya da unsurlar olarak tanımlanabilir. Bunlar; para, güvenlik, fedakarlık, kariyer gelişimi, prestij, yönetim, ekonomik getiri, estetik, yaratıcılık, entelektüel teşvik, başarı, bağımsızlık, çevre, yaşam tarzı, değişiklik, insan ilişkileri ve arzuladığ gibi belirli özellikler göstermektedir. Kişi bu değerlere ulaştıkça işinden o derece tatmin olacaktır (Super ve Sverko,1995).

Meslek seçimi; bireyin tercih ettiği meslekler arasından birini ayırması ve bu mesleğe girmek için çaba göstermesidir. Birey mesleğini seçerken, kendi bireysel özellikleri ile seçeceği mesleğin nitelikleri arasında bir uyum olmasına dikkat eder. Meslek seçimi, genç bireyin yaşamında vermek zorunda olduğu en önemli kararlardan birini oluşturmakta ve birçok faktörden etkilenen karmaşık bir karar verme sürecini içermektedir. Bireylerin meslek seçimlerini etkileyen faktörler arasında; yaş, cinsiyet, sahip olduğu kişilik özellikleri, ailesi, kardeş sayısı, yakın ilişkide bulunduğu kişiler, okul öncesi ve okul dönemindeki eğitimi, ihtiyaçları, sahip olduğu ilgileri ve değerler sistemi, benlik kavramı, genel ve özel yetenekleri, diğer kişilik özellikleri, içinde yaşadığı çevrenin özellikleri, ekonomideki mevcut iş alanları ve istihdam koşulları ile piyasadaki arz ve talep durumu sayılabilir (Y1lmaz vd., 2012).

Kariyer ise; bir taraftan bireyin iş yaşamında bulunduğu pozisyonlar ve bu pozisyonlarla ilgili tutum ve davranışları ile yaptığı işleri kapsarken diğer taraftan da bireyin çalışma yaşamı boyunca herhangi bir iş alanında ilerlemesi, deneyim ve beceri kazanmasıdır şeklinde tanımlanmaktadır (Aytaç, 1997; Erdoğmuş, 2003). Başka bir ifade ile kariyer, "bir bireyin istediği yaşam tarzını sağlamaya çalışabilmesi için uzun dönemde elde ettiği veya edeceği eğitim, yetenek ve deneyimler birikimi" şeklinde tanımlanabilir. Görüldüğü gibi kariyer, bir kimsenin yaşamının her hangi bir anında sahip olduğu bütün 
İsletme Bilimi Dergisi (JOBS), 2017; 5(1): 49-70. DOI: 10.22139/jobs.289552

Hacettepe

Üniversitesi

Sosyal Bilimler

Meslek

Yüksekokulu

Öğrencilerinin İş

Değerleri ve

Kariyer

Seçimlerinin

Doğrusal

Olmayan

Kanonik

Korelasyon

Analizi İle

Değerlendirilmesi

52 rollerin gerektirdiği etkinliklerin bileşimidir ve bu roller bireyin çalışan olarak üstlendiği rolleri de içerir (Uğurlu, 2007). Kariyer; bir insanın çalışabileceği yıllar boyunca herhangi bir iş alanında adım adım ve sürekli olarak ilerlemesi, deneyim ve beceri kazanmasıdır şeklinde de ifade edilebilir (Şimşek vd., 2004). İş değerleri ve meslek seçimleri, kariyer seçiminde etkili olan bir faktördür. Yapılan çalışmalara göre; bireysel değerler ile iş değerleri arasında önemli bir bağ bulunmaktadır. Kariyer değerleri, bir bireyin kendi kendine algıladığı yetenek ve kabiliyetleri, temel değerleri, güdü ve ihtiyaçlarından oluşan bir benlik kavramıdır. Kişiye özgü özelliklerden oluşan bu kombinasyon, bireyin kariyer seçiminde etkili olur. Kişisel değerler, insan davranışlarının belirlenmesinde önemli bir unsurdur. Bu değerler her insana göre farklılık göstermektedir. Bireylerin farklı özellikleri, farklı değerlere sahip olmalarını ve dolayısıyla farklı davranışlar sergilemelerine neden olmaktadır. Kişiler arasındaki en önemli farklılıklar; cinsiyet, yaş, eğitim durumu, aile yapısı, ailenin öğrenim durumu, yetiştikleri çevre, genetik özellikleri gibi demografik faktörlerin bir sonucudur. Bu faktörler, bireylerin iş değerlerinin oluşmasında da önemli rol oynamaktadır (Pilavcı, 2007).

Günümüzde kariyer, işin yeniden yapılandırılması yoluyla birey için anlamlı ve psikolojik olarak bireyi tatmin edici bir süreç haline gelmiştir ve bu süreçte ilerleme yerine, bilgi kazanma ve kendini geliştirme daha önemli hale gelmektedir (Erdoğmuş, 2003). Bu bakış açısıyla da kariyer gelişimi, motivasyonu yüksek ancak yönlendirilmesi eksik olan günümüz gençliği açısından yaşamsal bir önem arz etmektedir. Bu anlamda bireyler, üst düzey bir eğitim alma beklentisi ve mesleki kariyerlerinde ilerlemek amacıyla hırsa kapılmışlardır. Ancak yapılan araştırmalara göre bu bireylerin pek çoğunun hedeflerini geliştirmeye dönük tutarlı bir planları dahi bulunmamaktadır (Schneider ve Stevenson, 1999; Hughes ve Karp, 2004). Yukarıda da belirtildiği gibi, bir kişinin kariyeri, sadece onun sahip olduğu işler değil, işyerinde kendisine verilen iş rolüne ilişkin beklenti, amaç, duygu ve arzularını gerçekleştirebilmesi için eğitilmesi ve böylece sahip olduğu bilgi, beceri, yetenek ve çalışma arzusu ile o işletmede ilerleyebilmesi ve bireylerin kendi bilgi, beceri ve ilgilerini, güçlü ve zayıf yönlerini değerlendirmeleri, örgüt içi ve dişındaki fırsatları tanımlamaları, kısa, orta ve uzun dönemli amaçlarını belirlemeleri ve bunlara ilişkin planlar yapmaları anlamını taşımaktadır (Aytaç, 1997; Bolat ve Seymen, 2003).

Buradan da anlaşıldığı gibi kariyer planlaması, özellikle kariyerinin henüz başında olan genç bireyler açısından oldukça önemlidir. Eğitim alan bir 
bireye kariyer planlamada yardım edebilmenin anahtarı, onun geleceğine etki edebilecek kariyer planlaması faaliyetlerini gerçekleştirebileceği cesareti verebilmektir. Bu aşamada olan bireylerin, bilgi, beceri ve ilgilerini keşfetmeleri ve kariyer hedeflerini oluşturmaları konusunda onlara bilgi sağlayacak bir takım kariyer planlaması aktiviteleri bulunmaktadır. Kariyerle ilgili bilinmesi gereken bir gerçek var ki o da kişinin kendi kariyer gelişiminden yine kendisinin sorumlu olduğudur. Kariyer hedefleri konusunda tecrübeli insanlarla konuşmak, hedefledikleri kariyer ile ilgili bilgi sağlamalarına yardımcı olacak kurslara katılmak, part-time olarak çalışmak ya da staj yapmak gibi aktiviteler onlara iş ortamı, işin gerekleri hakkında bilgi edinmeleri ve bilgi, beceri ve isteklerinin seçimleri ile ne ölçüde uyumlu olduğunu görme imkanı sağlamaktadır (Pilavcı, 2007; Laker ve Laker, 2007; Walker ve Levesque, 2006).

Kariyer seçimine ilişkin olarak kullanılan teorilerden biri Holland'ın mesleki kişilik kuramıdır. Bu kurama göre; kendi ilgilerini ve yeteneklerini bilen bireyler, aktif bir şekilde kendilerine uygun bir kariyeri arayacaklardır. Holland'in bu kuramı; bireyin kişilik dinamiği ile mesleklerin içinde yürütüldüğü çevre ya da söz konusu mesleklerin gerektirdiği faaliyetler arasındaki ilişkiye dayanmaktadır. Holland, bireyin herhangi bir mesleğe olan ilgisinin, o bireyin kişiliğinin bir yansıması olduğunu ifade etmektedir. Bireyin değerlerini, ihtiyaçlarını ve güdülenmesini içeren kişiliğgi, onun kariyer seçimini belirleyen önemli bir faktördür. Holland, belirli kişilik özelliklerine sahip bireylerin, belirli tanımlanabilir nitelikteki işlere ilgi duyduklarını ve bu işler için uygun olduklarını kabul etmektedir. Holland'ın mesleki kişilik kuramının merkezinde dört temel varsayım yer almaktadır. Bu dört temel varsayıma göre:

1. Her bir birey; gerçekçi, araştırmacı, sanatçı, sosyal, girişimci ve geleneksel olmak üzere altı kişilik tipinden birinin özelliklerini sergilemektedir.

2. Kişilik tiplerine benzer bir biçimde; gerçekçi, araştırmacı, sanatçı, sosyal, girişimci ve geleneksel olmak üzere altı model çevre vardır.

3. Bireyler, kendi beceri ve yeteneklerini kullanabilecekleri, kendi tutum ve değerlerini dile getirebilecekleri, kişilikleriyle uyumlu konularla uğraşabilecekleri ve kişilikleriyle uyumlu rolleri üstlenebilecekleri uygun çevreler ararlar.

4. Bireye özgü davranış, kişilik ve çevre arasındaki etkileşimin bir sonucudur. 
İsletme Bilimi Dergisi (JOBS), 2017; 5(1): 49-70. DOI: 10.22139/jobs.289552

Hacettepe

Üniversitesi

Sosyal Bilimler

Meslek

Yüksekokulu

Öğrencilerinin İş

Değerleri ve

Kariyer

Seçimlerinin

Doğrusal

Olmayan

Kanonik

Korelasyon

Analizi İle

Değerlendirilmesi

\section{4}

Bu kurama göre; meslekler yürütüldükleri çevre modeli bakımından altı temel grupta toplanmakta olup, bu meslekleri yürütecek bireylerin kişilik tipleri de altı gruptan oluşmaktadır (Yılmaz vd., 2012).

Holland'ın altı kişilik tipi Tablo 1'de gösterilmektedir.

Tablo 1: Holland'ın 6 kişilik Tipi

\begin{tabular}{|c|c|c|c|}
\hline KİŞİLIK TİPI & $\begin{array}{c}\text { BELIRGİN } \\
\text { ÖZELLIKLLEİ }\end{array}$ & $\begin{array}{c}\text { BASKIN } \\
\text { TALEPLER/ETKİNLIKKLER }\end{array}$ & $\begin{array}{c}\text { TİPIK } \\
\text { MESLEKLER }\end{array}$ \\
\hline Gerçekçi & $\begin{array}{l}\text { Sabırlı ve hoşgörülü, } \\
\text { pratik, maddeci, } \\
\text { erkeksi, antisosyal, } \\
\text { uyumlu, içten, doğal, } \\
\text { sabırlı, iç görüleri ve } \\
\text { başarma güdüleri } \\
\text { fazla }\end{array}$ & $\begin{array}{l}\text { *Kas etkinliği, motor } \\
\text { koordinasyonu gerektiren işler } \\
\text { *Açık havadaki işler, mekanik, } \\
\text { sistematik çalışmalar } \\
{ }^{*} \text { Nesneler, eşyalar, makineler } \\
\text { ve hayvanlarla ilgili etkinlikler }\end{array}$ & $\begin{array}{l}\text { Otomobil tamircisi- } \\
\text { her çeşit araç } \\
\text { teknisyeni, } \\
\text { elektrikçi, } \\
\text { mühendis, ziraat ile } \\
\text { ilgili meslekler, } \\
\text { beden eğitimi } \\
\text { öğretmeni }\end{array}$ \\
\hline Araştırıcı & $\begin{array}{l}\text { Entelektüel, analitik } \\
\text { düşünce yapısına } \\
\text { sahip, rasyonel, } \\
\text { eleştirel, titiz, sabırlı, } \\
\text { yöntemci, bağımsız, } \\
\text { popüler olmaktan } \\
\text { hoşlanmayan }\end{array}$ & $\begin{array}{l}\text { *Analitik gözlem yapma } \\
\text { *Sistematik deneysel çalışma } \\
\text { *Fiziksel, biyolojik ve kültürel } \\
\text { olguları araştırma }\end{array}$ & $\begin{array}{l}\text { Biyolog, genetikçi, } \\
\text { matematikçi, } \\
\text { kimyager, fizikçi, } \\
\text { astronot, } \\
\text { antropolog, tıp } \\
\text { teknisyeni }\end{array}$ \\
\hline Artistik & $\begin{array}{l}\text { Heyecan ve coşkuları } \\
\text { dengesiz, hayalci, } \\
\text { fevri, karmaşık, } \\
\text { sezgileri güçlü, } \\
\text { bağımsız, duygusal, } \\
\text { uyumlu olmayan, } \\
\text { duyarlı ve etkileyici }\end{array}$ & $\begin{array}{l}\text { *Estetik faaliyetler yapar } \\
\text { *Tutkulu, bağımsız, sistematik } \\
\text { olmayan aktiviteler } \\
\text { *Sanatsal etkinlik ve ürünler } \\
\text { yaratma } \\
\text { *Bağımsız yaratıcı çalışmalar }\end{array}$ & $\begin{array}{l}\text { Yazar, ressam, } \\
\text { aktör, tiyatro } \\
\text { sanatçısı, müzisyen, } \\
\text { kompozitör, } \\
\text { dekoratör ve mimar }\end{array}$ \\
\hline Sosyal & $\begin{array}{l}\text { Yardımsever, } \\
\text { sorumluluk sahibi, } \\
\text { sosyal işbirliğine } \\
\text { yatkın, empatik, } \\
\text { arkadaş canlısı, içten, } \\
\text { sabırlı, nazik, } \\
\text { anlayışlı }\end{array}$ & $\begin{array}{l}\text { *Insanlarla birlikteliği saptayan } \\
\text { aktiviteler } \\
\text { *Başkalarını eğiterek } \\
\text { geliştirmek, yardım etmek } \\
\text { *Başkalarını ikna etme, } \\
\text { yönlendirme }\end{array}$ & $\begin{array}{l}\text { Sosyal hizmet } \\
\text { uzmanı, } \\
\text { rehabilitasyon } \\
\text { danışmanı, } \\
\text { psikolog, psikolojik } \\
\text { danışman, halkla } \\
\text { ilişkiler uzmanı, } \\
\text { üniversite öğretim } \\
\text { üyesi, öğretmen }\end{array}$ \\
\hline
\end{tabular}


Tablo 1: Holland'ın 6 kişilik Tipi (Devamı)

\begin{tabular}{|c|c|c|c|}
\hline Girişimci & $\begin{array}{l}\text { Dişa dönük, } \\
\text { enerjik, kendine } \\
\text { güvenli, atılgan, } \\
\text { fevri, ikna } \\
\text { yeteneği yüksek, } \\
\text { sabırsız, meraklı, } \\
\text { maceracı, iyimser, } \\
\text { sosyal, konuşkan }\end{array}$ & $\begin{array}{l}\text { *Başkalarını ikna etmeye } \\
\text { yönelik faaliyetler } \\
\text { *Sosyal eğlendirici } \\
\text { etkinlikler } \\
\text { *Organize edilmiş } \\
\text { çalışmalar }\end{array}$ & $\begin{array}{l}\text { Satıcı, } \\
\text { pazarlamacı, } \\
\text { komisyoncu, } \\
\text { menejer, } \\
\text { politikacı, avukat }\end{array}$ \\
\hline Geleneksel & $\begin{array}{l}\text { Dikkatli, titiz, } \\
\text { itaatkar, tutarlı, } \\
\text { esnek olmayan, } \\
\text { düzenli, sabırlı, } \\
\text { vicdanlı, } \\
\text { özdenetimli, hayal } \\
\text { gücünden yoksun, } \\
\text { dengeli }\end{array}$ & $\begin{array}{l}\text { *Sistemli kurallara bağlı } \\
\text { aktiviteler } \\
\text { *Nesnelerle ilgili sistematik } \\
\text { çalışmalar } \\
\text { *Kayıt tutma, hesaplama, } \\
\text { kontrol işlemleri, veri } \\
\text { işleme makineleri kullanma }\end{array}$ & $\begin{array}{l}\text { Banka veznedarı, } \\
\text { kütüphaneci, } \\
\text { daktilograf, } \\
\text { postacı, } \\
\text { muhasebeci, } \\
\text { kitapçı, finans } \\
\text { elemanı }\end{array}$ \\
\hline
\end{tabular}

Kaynak: http://www.meslek-secimi.com/FileUpload/ks716751/File/05_holland_ meslek_tercih_envanteri.pdf

$\mathrm{Bu}$ çalışmada, üniversite öğrencilerinin demografik özellikleri ile iş değerleri ve kariyer seçimleri arasındaki ilişki incelenmiştir.

\section{Yöntem}

\subsection{Araştırmanın Amacı}

$\mathrm{Bu}$ çalışmanın amacı, Hacettepe Üniversitesi Sosyal Bilimler Meslek Yüksekokulu'nda öğrenim gören öğrencilerin kariyer seçimlerini hangi faktörlerin etkilediğini belirlemek ve iş değerleri ile kariyer seçimleri arasında bir ilişki olup olmadığını ortaya koymaktır.

\subsection{Araştırma Evreni}

Araştırmanın evrenini; 2012-2013 eğitim öğretim yılında Hacettepe Üniversitesi Sosyal Bilimler Meslek Yüksekokulu'nun muhasebe, turizm ve otel işletmeciliği ve büro yönetimi programlarının birinci ve ikinci öğretiminde öğrenim gören toplam 617 öğrenci oluşturmaktadır.

\subsection{Araştırma Örneklemi}

2012-2013 eğitim öğretim yılında, Hacettepe Üniversitesi Sosyal Bilimler Meslek Yüksekokulu'nun muhasebe, turizm ve otel işletmeciliği ve büro yönetimi programlarında ders döneminde ulaşılabilen 300 öğrenci, araştırmanın örneklemini oluşturmaktadır. Kanonik korelasyon analizinde
Hacettepe

Üniversitesi

Sosyal Bilimler

Meslek

Yüksekokulu

Öğrencilerinin İş

Değerleri ve

Kariyer

Seçimlerinin

Doğrusal

Olmayan

Kanonik

Korelasyon

Analizi İle

Değerlendirilmesi

55 
İsletme Bilimi Dergisi (JOBS), 2017; 5(1): 49-70. DOI: 10.22139/jobs.289552

Hacettepe

Üniversitesi

Sosyal Bilimler

Meslek

Yüksekokulu

Öğrencilerinin İş

Değerleri ve

Kariyer

Seçimlerinin

Doğrusal

Olmayan

Kanonik

Korelasyon

Analizi İle

Değerlendirilmesi

56 örneklem genişliğinin kullanılan değişken sayısının en az 10 ile 20 katı arasında olması önerilmektedir (Salkind, 2010). Dolayısıyla ulaşılan 300 öğrenci kanonik korelasyonda örneklem genişliği için yeterli sayıdadır.

\subsection{Veri Toplama Arac1}

İş değerlerini belirlemek amacıyla kullanılan iş değerleri envanteri, Super'in (1969) iş değerlerini belirlemeye yönelik ölçeğindeki 45 sorudan oluşmaktadır. İş değerleri; fedakarlık, estetik, yaratıcılık, entelektüel teşvik, başarı, bağımsızlık, prestij, yönetim, ekonomik kazanç, güvenlik, çevre, yönetici ile ilişkiler, iş arkadaşları ile ilişkiler, yaşam tarzı ve değişikliktir. Her bir boyut için, önceki araştırma bulgularına ve literatür araştırmasına dayanan 3 ya da 4'er yargı hazırlanmış ve beşli Likert tipi ölçekle (1: Önemsiz, 2: Az Önemli, 3: Kısmen Önemli, 4: Önemli, 5: Çok Önemli) değerlendirilmiştir.

Anket çalışmasının üçüncü bölümünü, Holland'ın kariyer seçme envanterinden yola çıkılarak, mesleki ilgi ve kariyer seçimini ölçmeye yönelik sorular oluşturmaktadır. Holland'ın (1997) kariyer seçme envanteri; "gerçekçi", "araştırmacı","sanatçı", "sosyal", "girişimci" ve "geleneksel" olmak üzere altı faktörden oluşmaktadır. Her bir boyutu kapsayacak şekilde hazırlanan toplam 34 yargı, beşli Likert tipi ölçekle (1: Hiç Sevmem, 2: Sevmem, 3: Kararsızım, 4: Severim, 5: Çok Severim) değerlendirilmiştir.

Uygulanan anket formunda bu iki ölçeğin yanı sıra, ilk bölümde katılımcıların yaşı, cinsiyeti, mezun olduğu okulu, kayıtlı olduğu program, dönemi, çalışma durumu ve eğitim aldığı bölümü meslek olarak seçip seçmediği gibi demografik bilgiler de istenmiştir.

\section{5. İstatistiksel Analiz}

Analizlerde ilk olarak iş değerleri ve kariyer seçimi ölçekleri için güvenirlik analizi gerçekleştirilmiştir. Öğrencilerin tutumlarını ifade etmek için yer verilen iş değerleri ve kariyer seçimi ölçeklerinde her bir ölçek içindeki değişkenler arası bağımlılık yapısının ortadan kalkması, boyut küçültmek ve birbiriyle yüksek ilişkili değişkenleri birleştirmek amacıyla verilere faktör analizi uygulanmıştır. Öğrencilerin demografik özellikleri ile iş değerleri ve kariyer seçimleri arasındaki ilişkiyi ortaya koyabilmek için OVERALS'dan yararlanılmıştır (Tekin, 1993). Bu yöntem, değişkenlerin yer aldığı iki veya daha fazla küme arasındaki ilişkileri eş zamanlı olarak analiz eder. OVERALS'ın diğer çok değiş̧kenli yöntemlere göre avantajı, analize farklı ölçme düzeyine sahip (sayısal, sıralı ve sınıflayıcı) değişkenlerin dahil edilmesinin de söz 
konusu olmasıdır. Ayrıca analiz, standart Kanonik korelasyon yönteminden farklı olarak değişkenlerin dağılımı veya ilişkilerin doğrusallığı hakkında herhangi bir varsayımda bulunmaz. Sayısal değişkenlerin yanı sıra, kategorik değişkenleri de aynı anda analize dahil etmesi ve iki boyutlu haritalarda değişkenlerin grafiksel gösterimine de yer vermesi yöntemi kullanışlı yapmaktadır (Frie ve Janssen, 2009; Saraçlı ve Saraçlı, 2006).

Kanonik Korelasyon Analizi, bağımsız değişkenlerle oluşturulan küme ile bağımlı değişkenlerin oluşturduğu küme arasındaki ilişkinin derecesini ortaya koyan çok değişkenli istatistik analizlerinden biridir (Tekin, 1993). Kanonik Korelasyon analizinde amaç, her bir kümenin rastlantı değişkenlerinin maksimum korelasyonlu ve birim varyanslı olduğu birer doğrusal bileşenini elde etmektir (Tatlıdil, 2002; Mirtaghizadeh, 1990).

\section{Bulgular}

Uygulamada Hacettepe Üniversitesi Sosyal Bilimler Meslek Yüksekokulu'nun 3 programına 2012-2013 öğretim yılında devam eden 300 öğrenciye uygulanan anket aracılığı ile öğrencilerin demografik özellikleri ile iş değerleri ve kariyer seçimleri arasında bir ilişki olup olmadığı araştırılmış ve bu amaçla Doğrusal Olmayan Kanonik Korelasyon Analizinden (OVERALS) yararlanılmıştır.

İlk olarak kullanılan iş değeri ve kariyer seçimi ölçekleri için güvenirlik analizleri yapılmış Cronbach Alpha değerleri sırasıyla 0.929 ve 0.882 olarak bulunmuştur. Her iki ölçeğe uygulanan açıklayıcı faktör analizinde (Açıklayıcı faktör analizi uygulanmasının nedeni; çalışmada Holland'ın 6 faktörüne ek olarak "pazarlıkçı" boyutu da ortaya çıkmıştır. Burada amaç 45+34 soruyu ifade eden boyutları değişken gibi kullanarak OVERALS analizi ile ilişkileri incelemektir. Çalışma ölçek geliştirmeyi konu almadığından yapı geçerliği gösterilmemiştir) ilk olarak, değişkenler arasında ilişkilerin olup olmadığını görmek, verilere faktör analizi uygulamanın gerekliliğini sınamak, eğer değişkenler arasında ilişki varsa bunların önemli olup olmadığını anlamak amacıyla küresellik testi uygulanmıştır. Küresellik testi sonucunda (Tablo 2) KMO Testi için $p=0.000$ bulunmuş olup değişkenler arasındaki ilişkilerin \% 95 güven düzeyinde önemli olduğu söylenebilir.

İş değerleri ölçeğinin faktör analizi sonuçları Tablo 2'de, kariyer seçimi ölçeğinin faktör analizi sonuçları ise Tablo 3' de verilmiştir. 
İsletme Bilimi Dergisi (JOBS), 2017; 5(1): 49-70. DOI: 10.22139/jobs.289552

Hacettepe

Üniversitesi

Sosyal Bilimler

Meslek

Yüksekokulu

Öğrencilerinin İş

Değerleri ve

Kariyer

Seçimlerinin

Doğrusal

Olmayan

Kanonik

Korelasyon

Analizi İle

Değerlendirilmesi

58
Tablo 2' de görüldüğ̈̈ gibi öğrencilerin iş değerlerine yönelik tutumları on iki faktör altında toplanmaktadır. Bunlar sırasıyla; değişiklik, prestij ve yönetim, yönetici ile ilişki, başarı ve bağımsızlık, güvenlik, entelektüel teşvik, ekonomik kazanç, estetik, çevre, fedakarlık, iş arkadaşları ile ilişkiler ve yaratıcılıktır. Bu on iki faktör toplam varyansın \% 65'ini açıklamaktadır. Benzer şekilde Tablo 3'de öğrencilerin kariyer seçimine yönelik tutumları 7 faktöre ayrılmıştır. Kariyer seçimi alt grupları ise; Holland'ın kariyer seçme envanterine göre sanatçı, araştırmacı, gerçekçi, girişimci, sosyal ve geleneksel olmak üzere kategorize edilirken açılayıcı faktör analizi sonucuna göre yedinci faktör olan "pazarlıkçı" yapı da bu çalışma sonucunda bulgulara eklenmiştir. Bu 7 faktör, toplam varyansın \% 59.58' ini açıllamaktadır.

Tablo 2: İş Değerleri Ölçeği Açıklayıcı Faktör Analizi Sonuçları

\begin{tabular}{|c|c|c|c|c|c|c|c|}
\hline Faktörler & & & Faktö & Yükleri & $\begin{array}{c}\text { Açılanan } \\
\text { Varyans } \\
(\%)\end{array}$ & $\begin{array}{l}\text { Cronbach } \\
\text { Alpha }\end{array}$ & Özdeğer \\
\hline $\begin{array}{l}\text { Faktor 1- } \\
\text { Değişiklik } \\
\text { ID43 } \\
\text { ID44 } \\
\text { ID42 } \\
\text { ID40 } \\
\text { ID45 } \\
\text { ID41 }\end{array}$ & \begin{tabular}{|l|}
0.789 \\
0.691 \\
0.67 \\
0.549 \\
0.534 \\
0.507 \\
\end{tabular} & & & & 7.186 & 0.820 & 3.23 \\
\hline $\begin{array}{l}\text { Faktör 2-Prestij ve } \\
\text { yönetim } \\
\text { ID21 } \\
\text { ID22 } \\
\text { ID23 } \\
\text { ID20 } \\
\text { ID19 } \\
\end{array}$ & & $\begin{array}{l}0.665 \\
0.66 \\
0.627 \\
0.605 \\
0.582 \\
\end{array}$ & & & 6.69 & 0.768 & 3.01 \\
\hline $\begin{array}{l}\text { Faktör 3- Yönetici } \\
\text { ile iliş̧ki } \\
\text { ID35 } \\
\text { ID34 } \\
\text { ID36 } \\
\end{array}$ & & & \begin{tabular}{|l|}
.722 \\
0.72 \\
0.689 \\
\end{tabular} & & 6.56 & 0.839 & 2.95 \\
\hline $\begin{array}{l}\text { Faktör 4- Başarı ve } \\
\text { bağımszlık } \\
\text { ID15 } \\
\text { ID14 } \\
\text { ID17 } \\
\text { ID13 } \\
\text { ID16 } \\
\text { ID18 } \\
\end{array}$ & & & & \begin{tabular}{|l|}
0.653 \\
0.617 \\
0.617 \\
0.601 \\
0.555 \\
0.49 \\
\end{tabular} & 6.2 & 0.802 & 2.79 \\
\hline
\end{tabular}


Tablo 2'nin Devamı

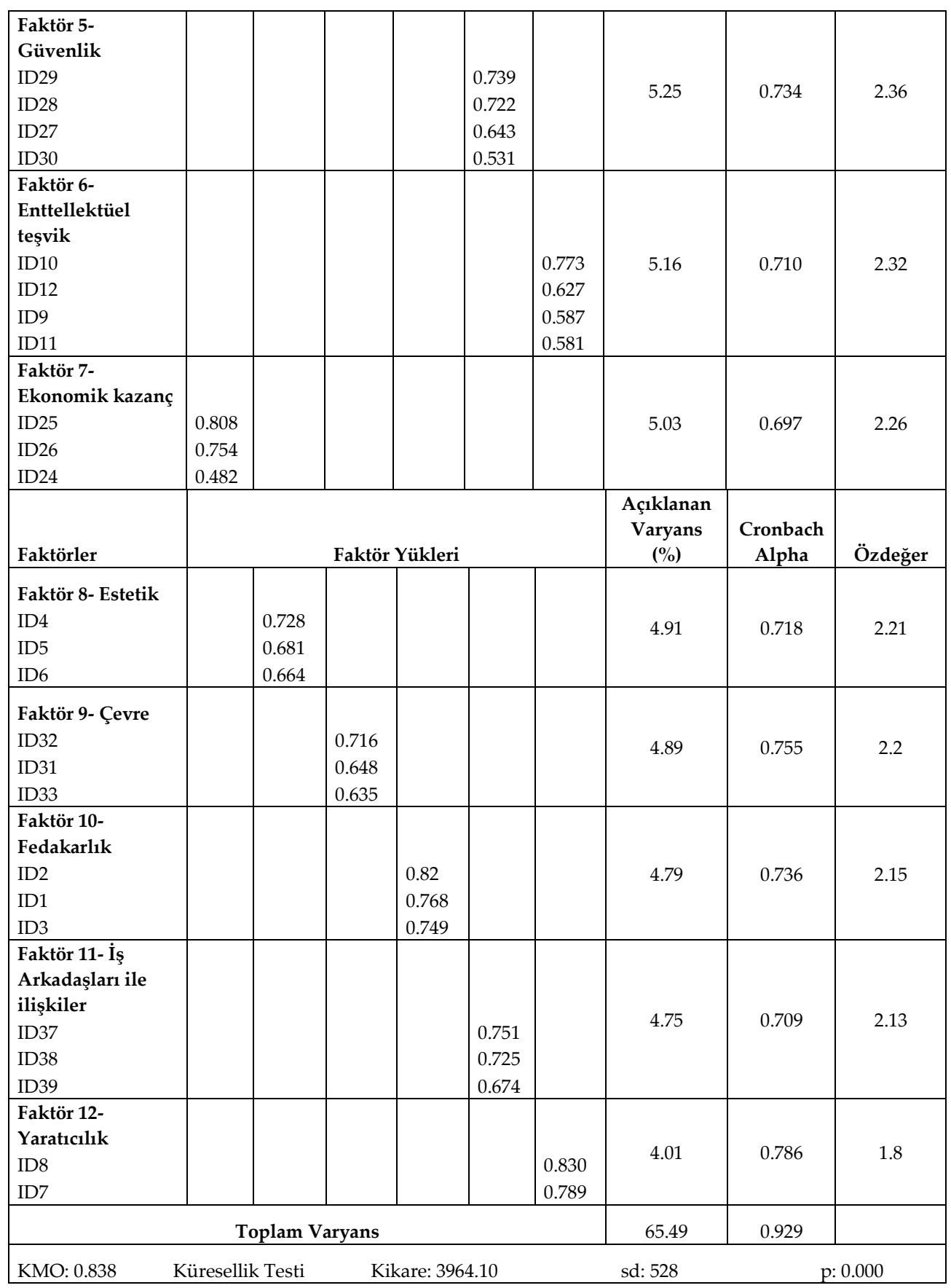

Hacettepe

Üniversitesi Sosyal Bilimler

Meslek

Yüksekokulu

Öğrencilerinin İş

Değerleri ve

Kariyer

Seçimlerinin

Doğrusal

Olmayan

Kanonik

Korelasyon

Analizi İle

Değerlendirilmesi

59 
İşletme Bilimi Dergisi (JOBS), 2017; 5(1): 49-70. DOI: 10.22139/jobs.289552

Hacettepe

Üniversitesi

Sosyal Bilimler

Meslek

Yüksekokulu

Öğrencilerinin İş

Değerleri ve

Kariyer

Seçimlerinin

Doğrusal

Olmayan

Kanonik

Korelasyon

Analizi İle

Değerlendirilmesi
Tablo 3: Kariyer Seçimi Ölçeği Açıklayıcı Faktör Analizi Sonuçları

\begin{tabular}{|c|c|c|c|c|c|c|c|c|c|c|}
\hline Faktörler & & & & ktör $Y i$ & kleri & & & $\begin{array}{c}\text { Açıklanan } \\
\text { Varyans(\%) }\end{array}$ & $\begin{array}{l}\text { Cronbach } \\
\text { Alpha }\end{array}$ & Özdeğer \\
\hline $\begin{array}{l}\text { Faktör 1- } \\
\text { Sanatçı } \\
\text { KS16 } \\
\text { KS18 } \\
\text { KS14 } \\
\text { KS13 } \\
\text { KS17 } \\
\text { KS15 }\end{array}$ & $\begin{array}{l}0.754 \\
0.736 \\
0.712 \\
0.672 \\
0.671 \\
0.621\end{array}$ & & & & & & & 10.28 & 0.821 & 3.393 \\
\hline $\begin{array}{l}\text { Faktör 2- } \\
\text { Araştırmacı } \\
\text { KS8 } \\
\text { KS11 } \\
\text { KS10 } \\
\text { KS12 } \\
\text { KS9 }\end{array}$ & & $\begin{array}{l}0.771 \\
0.754 \\
0.728 \\
0.721 \\
0.580 \\
\end{array}$ & & & & & & 9.831 & 0.829 & 3.244 \\
\hline $\begin{array}{l}\text { Faktör 3- } \\
\text { Gerçekçi } \\
\text { KS2 } \\
\text { KS4 } \\
\text { KS3 } \\
\text { KS1 } \\
\text { KS5 } \\
\text { KS7 }\end{array}$ & & & \begin{tabular}{|l|}
0.734 \\
0.729 \\
0.718 \\
0.703 \\
0.698 \\
0.527 \\
\end{tabular} & & & & & 9.39 & 0.798 & 3.101 \\
\hline $\begin{array}{l}\text { Faktör 4- } \\
\text { Girişimci } \\
\text { KS29 } \\
\text { KS28 } \\
\text { KS26 } \\
\text { KS27 } \\
\text { KS30 }\end{array}$ & & & & $\begin{array}{l}0.757 \\
0.74 \\
0.686 \\
0.613 \\
0.566\end{array}$ & & & & 8.6 & 0.773 & 2.839 \\
\hline $\begin{array}{l}\text { Faktör 5- } \\
\text { Sosyal } \\
\text { KS21 } \\
\text { KS22 } \\
\text { KS20 } \\
\text { KS19 } \\
\text { KS23 } \\
\end{array}$ & & & & & \begin{tabular}{|l|}
0.798 \\
0.738 \\
0.652 \\
0.632 \\
0.502 \\
\end{tabular} & & & 8.41 & 0.786 & 2.777 \\
\hline $\begin{array}{l}\text { Faktör 6- } \\
\text { Geleneksel } \\
\text { KS32 } \\
\text { KS33 } \\
\text { KS31 } \\
\text { KS34 }\end{array}$ & & & & & & $\begin{array}{l}0.824 \\
0.724 \\
0.673 \\
0.653 \\
\end{array}$ & & 7.62 & 0.773 & 2.515 \\
\hline $\begin{array}{l}\text { Faktör 7- } \\
\text { Pazarlıkçı } \\
\text { KS25 } \\
\text { KS24 }\end{array}$ & & & & & & & $\begin{array}{l}0.798 \\
0.789\end{array}$ & 5.42 & 0.773 & 1.790 \\
\hline \multicolumn{8}{|c|}{ Toplam Varyans } & $\begin{array}{c}59.58 \\
90\end{array}$ & $\begin{array}{r}0.882 \\
\end{array}$ & \\
\hline
\end{tabular}


Faktör analizi sonuçlarından elde edilen iş değerleri için 12 faktör ve kariyer seçimi için 7 faktör ile öğrencilerin demografik özellikleri arasındaki ilişkileri ortaya koymak için iki farklı OVERALS analizi yapılmıştır.

$\mathrm{Bu}$ amaçla faktör analizi sonucu elde edilen 12 faktörün ortalama puanları alınmış ve faktör ortalaması 3'ün altında kalanlar (ilgili yargı cümlesinde önemsiz ve az önemli görüşünü belirtenler) olumsuz tutum, 3'ün üstünde olanlar ise (ilgili yargı cümlesinde kısmen önemli, önemli, çok önemli görüşünü belirtenler) olumlu tutum olarak sınıflandırılmıştır. Benzer işlemler 7 faktörlü kariyer seçimi ölçeği için de gerçekleştirilmiştir.

\section{Demografik Özellikler İle Işs Değerleri Arasındaki İlişkinin OVERALS İle Incelenmesi}

OVERALS çözümünde 1. ve 2. boyutlarda uyumu (özdeğerleri) sırasıyla 0.71 ve 0.66 olmak üzere toplam uyum 1.37 bulunmuştur. Bu değerler, nicelleştirilen değişkenlerle nesne skorları arasındaki kanonik korelasyon katsayılarının karekökleridir ve oldukça iyi bir uyumu ifade etmektedir. OVERALS Katsayıları ise birinci boyut için 0.842 ve ikinci boyut için ise 0.812'dir. Çalışma grubu için nesne skorları ile dönüştürülmüş değişkenler arasındaki korelasyonu gösteren bileşen yükleri şekil 1'de vektörler olarak ve tablo 4'te sayısal olarak gösterilmiştir.

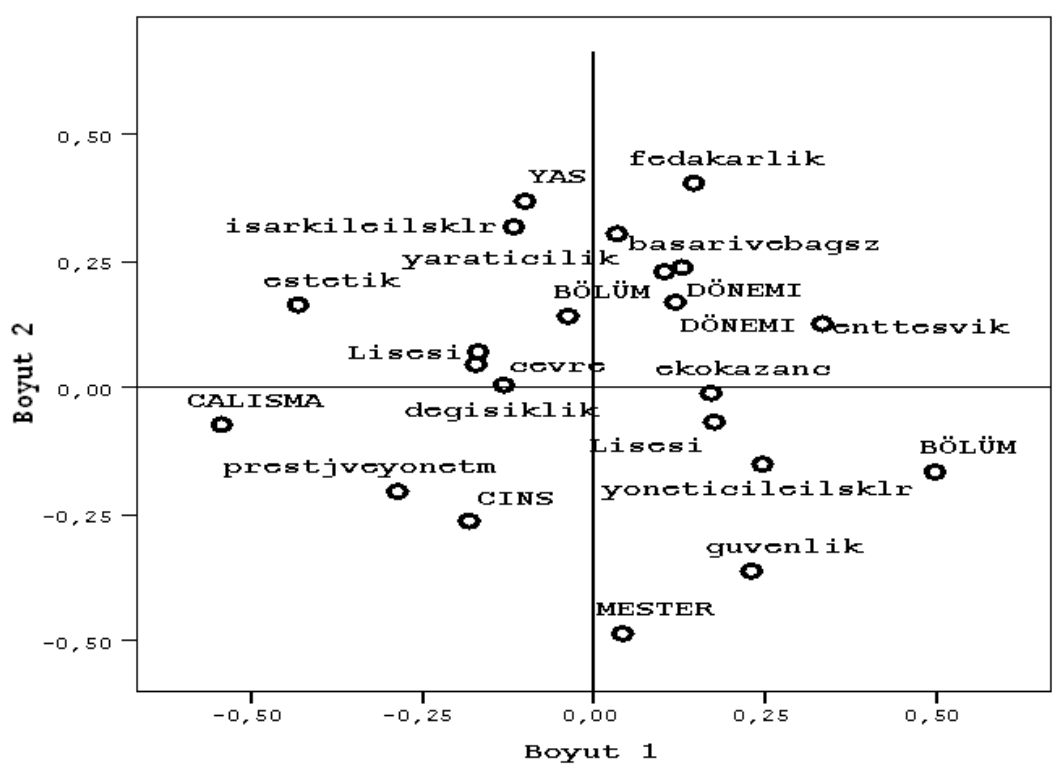

Şekil 1: Demografik Özellikler ve İş Değerleri İçin OVERALS Bileşen

\section{Yüklerinin İki Boyutlu Gösterimi}

Hacettepe

Üniversitesi

Sosyal Bilimler

Meslek

Yüksekokulu

Öğrencilerinin İş

Değerleri ve

Kariyer

Seçimlerinin

Doğrusal

Olmayan

Kanonik

Korelasyon

Analizi İle

Değerlendirilmesi

61 
İşletme Bilimi Dergisi (JOBS), 2017; 5(1): 49-70. DOI: 10.22139/jobs.289552

Hacettepe

Üniversitesi

Sosyal Bilimler

Meslek

Yüksekokulu

Öğrencilerinin İş

Değerleri ve

Kariyer

Seçimlerinin

Doğrusal

Olmayan

Kanonik

Korelasyon

Analizi İle

Değerlendirilmesi

62
Tablo 4: Demografik Özellikler ve İş Değerleri İçin OVERALS Bileşen Yükleri

\begin{tabular}{lrr}
\hline Değişken & Boyut 1 & Boyut 2 \\
\hline YAŞ & -0.101 & 0.369 \\
Cinsiyet & -0.182 & -0.263 \\
Lise & 0.176 & -0.067 \\
& -0.169 & 0.071 \\
Bölüm & 0.498 & -0.166 \\
& -0.038 & 0.141 \\
Dönem & 0.129 & 0.238 \\
& 0.119 & 0.170 \\
Çalışma & -0.544 & -0.072 \\
Mes/terc & 0.042 & -0.485 \\
Fedakarlık & 0.146 & 0.404 \\
Estetik & -0.433 & 0.164 \\
Yaratıcılık & 0.034 & 0.305 \\
Ent.teşvik & 0.334 & 0.127 \\
Başarı ve bağımsızlık & 0.103 & 0.230 \\
Prestij ve yönetim & -0.287 & -0.205 \\
Eko. kazanç & 0.171 & -0.010 \\
Güvenlik & 0.230 & -0.362 \\
Çevre & -0.172 & 0.046 \\
Yönetici ile ilişkiler & 0.246 & -0.150 \\
İş arkadaşı ile ilişki & -0.117 & 0.318 \\
Değişiklik & -0.132 & 0.006 \\
\hline
\end{tabular}

Ekonomik kazanç, yönetici ile ilişkiler ve güvenlik arasında aynı yönlü, kuvvetli bir ilişki gözlenmiştir. Yaş, değişiklik, iş arkadaşları ile ilişkiler ve çevre ile ilgili görüşler aynı yönlü ve kuvvetli ilişkilidir. Fedakarlık, başarı ve bağımsızlık aynı yönde yüksek ilişkili iken, bu değişkenler prestij, yönetim ve değişiklik ile ters yönlü kuvvetli ilişkiye sahiptir. 


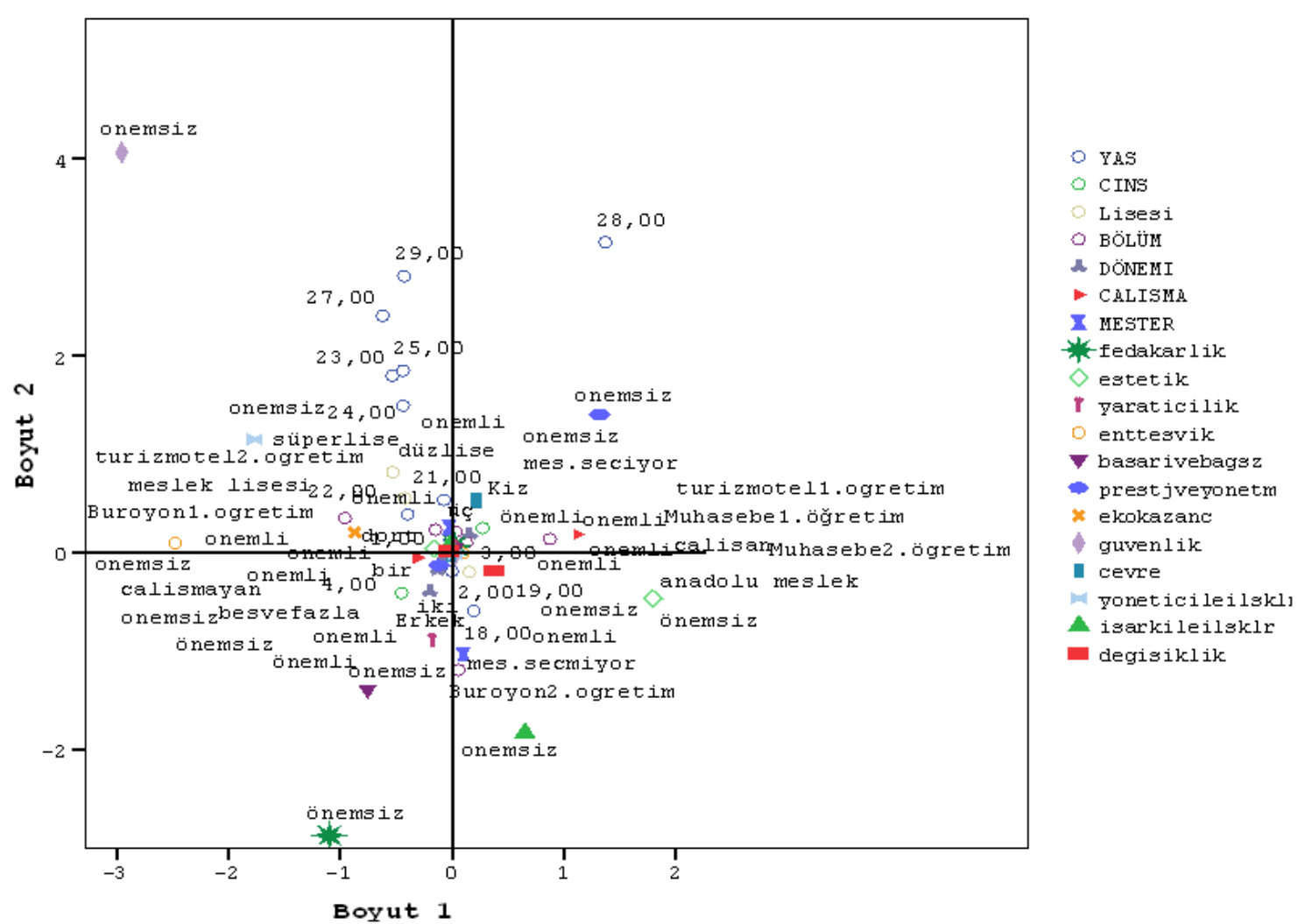

Hacettepe Universitesi yal Bilimler Meslek iksekokulu cilerinin İş Jeğerleri ve Kariyer eçimlerinin

Doğrusal

Olmayan

Kanonik

Korelasyon Analizi İle endirilmesi

\section{Şekil 2: Demografik Özellikler ve İş Değerleri İ̧̧in OVERALS Çoklu Kategori Koordinatları}

Kategori nicelleştirmesini resimlendiren Şekil 2, nesne skorlarının nasıl yorumlanacağını göstermektedir. 3. ya da 4. dönemde olan, 20-22 yaş arası, değişiklik, estetik, çevre ve entelektüel teşvik'i önemli bulan, okuduğu bölümü meslek olarak tercih eden, genellikle turizm programı 1 . ve 2 . öğretim kız öğrenciler homojen bir grup oluşturmuştur.

Estetiği önemli bulmayan, çalışmayan, okuduğu bölümü meslek olarak tercih etmeyen, başarı ve bağımsızlığı, yaratıcılığı önemsiz bulan, büyük kısmı muhasebe ya da büro yönetimi II. Öğretim öğrencisi olan erkekler diğer homojen bir grup olarak belirlenmiştir.

Demografik Özellikler İle Kariyer Seçimi Arasındaki İlişkinin OVERALS İle Incelenmesi

Ek 2.2'deki OVERALS çözümünde 1. ve 2. boyutlarda uyum (özdeğerler) sırasıyla 0.72 ve 0.71 olmak üzere toplam uyum 1.43 bulunmuştur. Bu değerler, 
İsletme Bilimi Dergisi (JOBS), 2017; 5(1): 49-70. DOI: 10.22139/jobs.289552

Hacettepe

Üniversitesi

Sosyal Bilimler

Meslek

Yüksekokulu

Öğrencilerinin İş

Değerleri ve

Kariyer

Seçimlerinin

Doğrusal

Olmayan

Kanonik

Korelasyon

Analizi İle

Değerlendirilmesi

64 nicelleştirilen değişkenlerle nesne skorları arasındaki kanonik korelasyon katsayılarının karekökleridir. Doğrusal Olmayan Kanonik Korelasyon Katsayıları ise birinci boyut için 0.848 ve ikinci boyut için ise 0.842 'dir. Bu değerler her iki boyutta da ele alınan değişken kümeleri arasında pozitif yönde kuvvetli bir ilişki olduğunu göstermektedir.

Çalışma grubu için nesne skorları ile dönüştürülmüş değişkenler arasındaki korelasyonu gösteren bileşen yükleri tablo 5 'te sayısal olarak ve şekil 3' de vektörler olarak gösterilmiştir.

Tablo 5: Demografik Özellikler ve Kariyer Seçimi İçin OVERALS Bileşen Yükleri

\begin{tabular}{lrr}
\hline Değişken & Boyut 1 & Boyut 2 \\
\hline YAŞ & 0.066 & 0.197 \\
Cinsiyet & -0.723 & 0.174 \\
Lise & -0.020 & -0.111 \\
& -0.043 & 0.119 \\
Bölüm & 0.286 & 0.260 \\
& 0.089 & 0.735 \\
Dönem & 0.192 & 0.084 \\
& 0.117 & 0.045 \\
Çalışma & 0.123 & -0.214 \\
Mes/terc & -0.292 & -0.063 \\
Gerçekçi & -0.383 & 0.240 \\
Araştırıc1 & 0.260 & -0.095 \\
Sanatçı & 0.503 & -0.248 \\
Sosyal & 0.349 & 0.007 \\
Pazarlıkçı & -0.137 & -0.490 \\
Girişimci & -0.074 & -0.086 \\
Geleneksel & 0.343 & 0.494 \\
\hline
\end{tabular}

Bileşen yükleri, cinsiyetin, sanatçı yapının ve sosyal yapının birinci boyut, pazarlıkçı yapının 2. boyut, çalışma durumu, gerçekçi yapı ve geleneksel yapının her iki boyut tarafından temsil edildiğini göstermektedir.

Araştırıcı, sosyal, girişimci, sanatçı yapı ve çalışma durumu arasında aynı yönlü, kuvvetli bir ilişki gözlenmiştir (Şekil 3). Çalışan öğrencilerin daha girişimci, daha sosyal ve daha araştırmacı bir yapıda oldukları söylenebilir. 


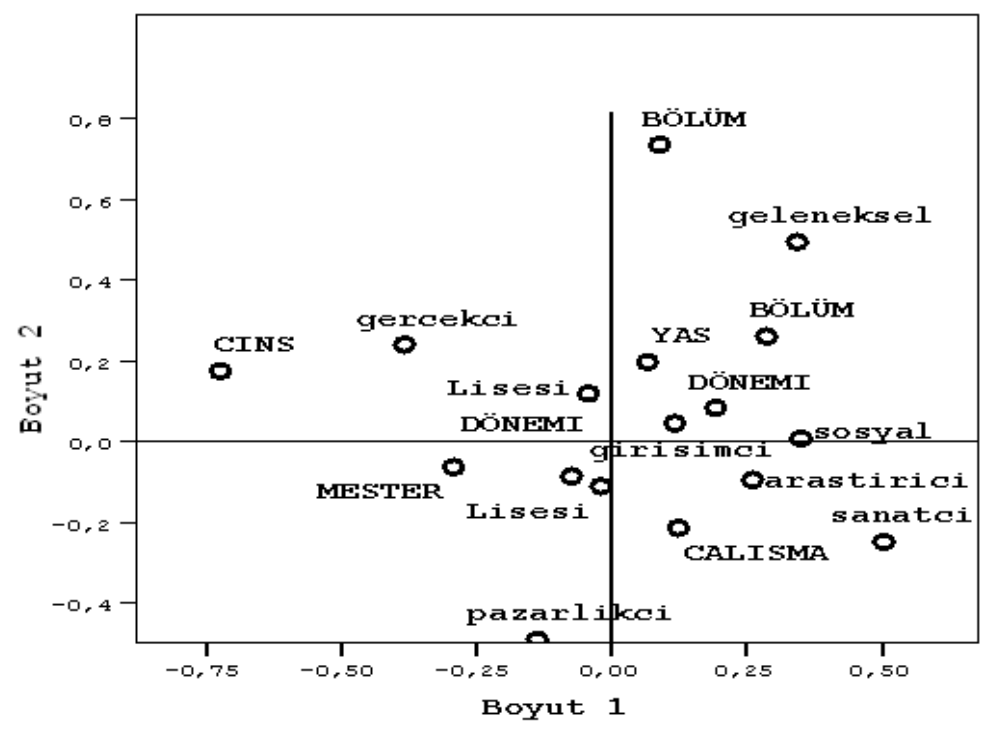

Şekil 3: Demografik Özellikler ve Kariyer Seçimi İçin OVERALS Bileşen Yüklerinin İki Boyutlu Gösterimi

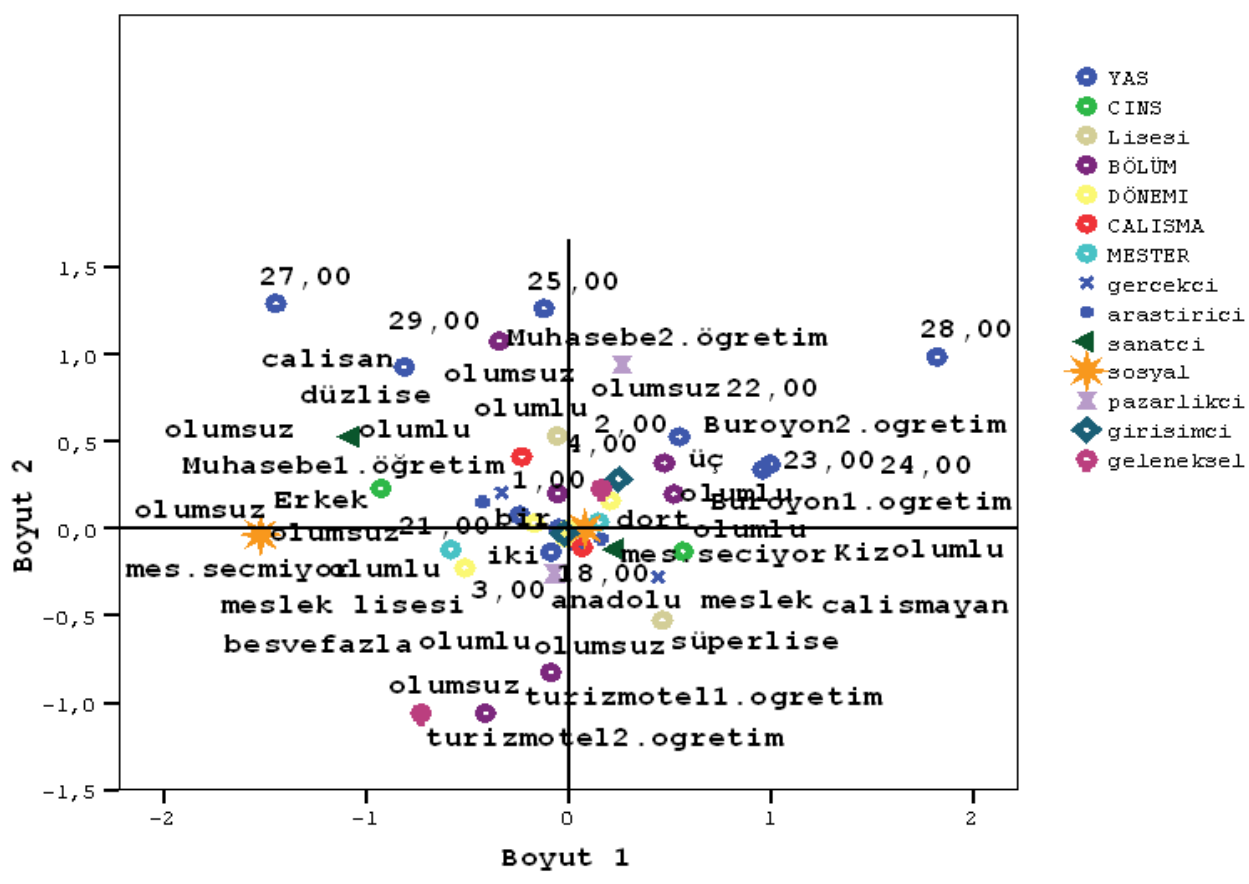

Hacettepe

Üniversitesi Sosyal Bilimler

Meslek

Yüksekokulu

Öğrencilerinin İş

Değerleri ve

Kariyer

Seçimlerinin

Doğrusal

Olmayan

Kanonik

Korelasyon

Analizi İle

Değerlendirilmesi

65

Şekil 4: Demografik Özellikler ve Kariyer Seçimi İçin OVERALS Çoklu Kategori Koordinatları 
İsletme Bilimi Dergisi (JOBS), 2017; 5(1): 49-70. DOI: 10.22139/jobs.289552

Hacettepe

Üniversitesi

Sosyal Bilimler

Meslek

Yüksekokulu

Öğrencilerinin İş

Değerleri ve

Kariyer

Seçimlerinin

Doğrusal

Olmayan

Kanonik

Korelasyon

Analizi İle

Değerlendirilmesi

66

Geleneksel yapı ile pazarlıkçı yapı arasında ters yönlü ilişki vardır. Yani geleneksel yapı arttıkça pazarlıkçı yapı azalmaktadır (Şekil 3).

Demografik özellikler ve kariyer seçimi için çoklu kategori koordinatları Şekil 4'te gösterilmiştir. Muhasebe 1. öğretim ve büro yönetimi 2. öğretimdeki büyük kısmı çalışan erkek öğrenciler, gerçekçi ve geleneksel bakışa sahip olup, araştırıcı ve girişimci bakış açısından olumsuz tutum sergilemektedirler. Okuduğu bölümü meslek olarak tercih eden çalışmayan kız öğrenciler, sosyal, araştırıcı ve sanatçı tutuma yönelirken, gerçekçi tutuma olumsuz bakmaktadırlar. Turizm ve Otel işletmeciliği 1. ve 2. öğretim öğrencileri genel olarak gelenekçi tutuma olumsuz bakmaktadırlar (Şekil 4).

Demografik özellikler, iş değerlerine ilişkin 12 faktör ve kariyer seçimine ilişkin 7 faktör arasındaki ilişkilere OVERALS ile bakıldığında doğrusal olmayan kanonik korelasyon katsayıları birinci boyut için 0.738 , ikinci boyut için 0.732 olarak elde edilmiştir.

\section{Sonuçlar}

Çalışmada elde edilen bulgular OVERALS optimal ölçeklendirme yönteminin değişik ölçüm düzeylerini içeren birbiri ile bağıntılı psikolojik değişkenler arasındaki ilişkileri incelemede yararlı olacağını göstermektedir. Özellikle OVERALS yönteminin birlikte hareket etmesi beklenen, fakat aralarında çoklu doğrusal bağıntı bulunan değişkenler arasındaki ilişkileri yakalamakta yararlı olduğu gözlenmiştir.

Öğrencilerin demografik özellikleri, iş değerleri ve kariyer seçimleri arasındaki ilişkiler ayrı ayrı üç değişken seti olarak tanımlanarak Doğrusal Olmayan Kanonik Korelasyon Analizi ile incelenmiştir.

Fedakarlık, estetik, yaratıcılık ve çevre faktörlerini önemli bulanlar kariyer seçimlerinde sosyal ve araştırmacı tutuma yönelmişlerdir. Gerçekçi tutuma olumlu bakanlar genel olarak ekonomik kazanca önem vermektedirler. Yönetici ve iş arkadaşları ile ilişkileri önemli bulanlar, araştırmacı, sosyal, pazarlıkçı, girişimci ve geleneksel yapıya olumlu bakış sergilemiştir. Okuldaki eğitimin 3. döneminde bulunan veya 5 ve daha fazla dönem okuyan erkek öğrenciler okuduğu bölümü meslek olarak tercih etmemekte, estetik, yaratıcılık, çevre ve güvenliği önemsiz bulmakta, sanatçı ve sosyal davranış açısından olumsuz tutum sergilemektedirler. Ekonomik kazancı önemsiz bulan kız öğrenciler süper lise ya da meslek lisesi mezunu olup gerçekçi tutuma da olumsuz bakmaktadırlar. Çalışan öğrenciler genellikle ekonomik kazancı 
önemli bulmakta, yönetim ve prestiji önemsiz bulmakta, pazarlıkçı tutuma da olumsuz bakmaktadırlar.

\section{Kaynaklar}

Aytaç, S. (1997). Çalışma Yaşamında Kariyer Yönetimi Planlaması Geliştirilmesi Yönetimi. İstanbul: Epsilon Yayınları.

Bolat T. ve Seymen O.A. (2003). Örgütlerde İş Etiği ve Kariyer Yönetimi İlişkisi: Normatif Etik Boyutuyla Bir Değerlendirme. İstanbul Üniversitesi Işsletme Fakültesi, İşletme İktisadı Enstitüsü Dergisi: Yönetim, (13)45: 3-19.

Erdoğmuş, N. (2003). Kariyer Geliştirme, Kuram ve Uygulama. Ankara: Nobel Yayın ve Dağıtım.

Frie K. G. ve Janssen C. (2009). Social Inequality, Lifestyles and Health-a Nonlinear Canonical Correlation Analysis Based on The Approach of Pierre Bourdieu. International Journal of Public Health, 54(4): 213-221.

Holland, J. L. (1997). Making Vocational Choices: A Theory of Vocational Personality and Work Environments, Psychological Assessment Resources, Inc., Florida.

Hughes, K.L. ve Karp, M.M. (2004). School-Based Career Development: A Synthesis of the Literature. Columbia.

Laker D.R. ve Laker R. (2007). The Five-Year Resume: A Career Planning Exercise. Journal of Management Education, 31(1): 128-141.

Mirtaghizadeh, H., (1990). Kanonik Korelasyon Analizi Üzerine Bir Deneme, Yayınlanmamış Yüksek Lisans Tezi, Ankara: Gazi Üniversitesi, Fen Bilimleri Enstitüsü.

Pilavcı, D., (2007). Bilgi Çağında Değişen Kariyer Anlayışı ve Üniversite Öğrencilerinin Kariyer Tercihlerini Etkileyen Faktörler Üzerine Bir Uygulama, Yayınlanmamış Yüksek Lisans Tezi, Adana: Çukurova Üniversitesi, Sosyal Bilimler Enstitüsü.

Salkind, N.J. (2010). Encyclopedia of Research Design (Vol. 1). SAGE Publication, Inc.

Saraçlı Z. ve Saraçlı S. (2006). Eskişehir Osmangazi Üniversitesi İ̈̈BF Öğrencilerinin Demografik Özellikleri İle Üniversite Sorunları Arasındaki İlişkinin Doğrusal Olmayan Kanonik Korelasyon Analizi İle İncelenmesi. Eskişehir Osmangazi Üniversitesi İIBF Dergisi, 1(1): 27-38. 
İsletme Bilimi Dergisi (JOBS), 2017; 5(1): 49-70. DOI: 10.22139/jobs.289552

Hacettepe

Üniversitesi

Sosyal Bilimler

Meslek

Yüksekokulu

Öğrencilerinin İş

Değerleri ve

Kariyer

Seçimlerinin

Doğrusal

Olmayan

Kanonik

Korelasyon

Analizi İle

Değerlendirilmesi

68
Schneider, B. ve Stevenson, D. (1999). The Ambitious Generation: Americans Teenagers, Motivated But Directionless. New Haven: Yale University Press.

Super, D. E. (1969). Manual: Work Values Inventory. Boston: Houghton Mifflin.

Super, D. E. ve Sverko, B. (1995). Life Roles, Values and Careers: International Findings of the Work Importance Study. San Francisco: Jossey-Bass Inc.

Şimşek, M.Ş., Akgemci, T., Çelik, A., Soysal, A. (2004). Kariyer Yönetimi ve İnsan Kaynakları Yönetimi Uygulamaları. Ankara: Gazi Kitabevi.

Tatlıdil, H. (2002). Uygulamalı Çok Değişkenli İstatistiksel Analiz. Ankara: Ziraat Matbaacilık.

Tekin, M., (1993). Kanonik Korelasyon Analizi ve Bir Uygulama, Yayınlanmamış Doktora Tezi, İstanbul: İstanbul Üniversitesi, Sosyal Bilimler Enstitüsü.

Uğurlu, O. (2007). Kariyer Değerleri: Lise Öğrencilerinin Kariyer Değerleri Üzerine Bir Araştırma, Dönem Projesi, Ankara: Ankara Üniversitesi, Sosyal Bilimler Enstitüsü, İnsan Kaynakları Yönetimi ve Kariyer Danışmanlığı Anabilim Dalı.

Yılmaz İ.A., Dursun B., Pektaş K. ve Altay A. (2012). Üniversite Öğrencilerinin Kariyer Seçimlerinin Demografik Özellikler Açısından İncelenmesi: Pınarhisar MYO Örneği. Ejovoc (Electronic Journal of Vocational Colleges), 2(2): 9-21.

Walker H.F. ve Levesque J. (2006). Climbing the Career Ladder : It is up to You. Quality Progress, (39)10: 28-32.

http://www.meslek-secimi.com/FileUpload/ks716751/File/05 holland meslek tercih envanteri.pdf $(03.10 .2016)$ 
Ek 1.1: İş Değerlerine İlişkin 12 Faktör İle Demografik Değişkenlere Ait Obje Skorları Grafiği

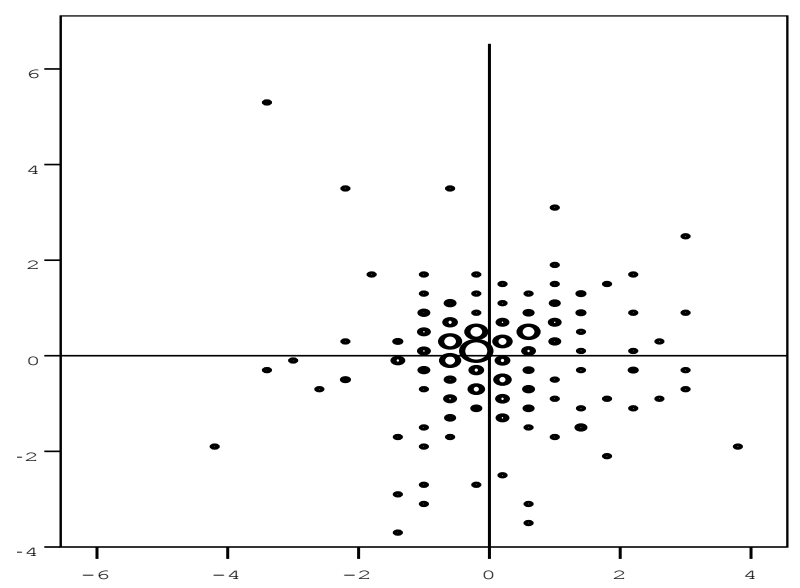

Ek 1.2: 12 İş Değeri Faktörü İle Demografik Değişkenlerine Ait OVERALS Sonuçları Tablosu

\begin{tabular}{|ll|r|r|r|}
\hline & \multicolumn{3}{|c|}{ Boy ut } & \multirow{2}{*}{} \\
\cline { 3 - 4 } & & \multicolumn{1}{|c|}{1} & \multicolumn{1}{c|}{ Toplam } \\
\hline Kay ip & Küme 1 &, 289 &, 341 &, 631 \\
& Küme 2 &, 289 &, 341 &, 631 \\
& Ortalama &, 289 &, 341 &, 631 \\
Ozdeger & &, 711 &, 659 & \\
Uy um & & & 1,369 \\
\hline
\end{tabular}


İşletme Bilimi Dergisi (JOBS), 2017; 5(1): 49-70. DOI: 10.22139/jobs.289552

Hacettepe

Üniversitesi

Sosyal Bilimler

Meslek

Yüksekokulu

Öğrencilerinin İş

Değerleri ve

Kariyer

Seçimlerinin

Doğrusal

Olmayan

Kanonik

Korelasyon

Analizi İle

Değerlendirilmesi

70
Ek 2.1: Kariyer Seçimine İlişkin 7 Faktör İle Demografik Değişkenlere Ait Obje Skorları Grafiği

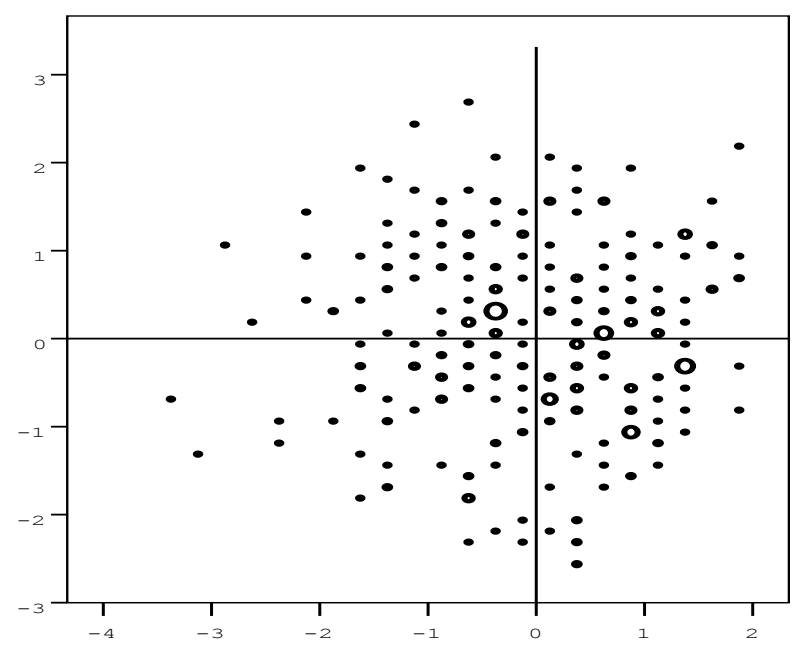

Ek 2.2: Yedi Kariyer Seçimi Faktörü İle Demografik Değişkenlere Ait OVERALS Sonuçlan Tablosu

\begin{tabular}{|ll|r|r|r|}
\hline & \multicolumn{3}{|c|}{ Boy ut } & \multirow{2}{*}{ Toplam } \\
\cline { 3 - 4 } & & \multicolumn{1}{|c|}{1} & \multicolumn{1}{c|}{2} &, 571 \\
\hline Kay ip & Kume 1 &, 281 &, 290 &, 567 \\
& Kume 2 &, 281 &, 286 &, 567 \\
& Ortalama &, 281 &, 288 &, 569 \\
Ozdeger & &, 719 &, 712 & \\
Uy um & & & 1,431 \\
\hline
\end{tabular}

